\title{
Alterations in mineral nutrients in soybean grain induced by organo-mineral foliar fertilizers
}

\author{
Vesna Dragičević ${ }^{*}$, Bogdan Nikolić ${ }^{2}$, Hadi Waisi ${ }^{3}$, Milovan Stojiljković ${ }^{4}$ Sanja Đurović ${ }^{2}$, Igor Spasojević \\ and Vesna Perić ${ }^{1}$
}

\begin{abstract}
Background: Chemical composition of soybean grain may be modified by application of foliar fertilizers. The aim of this study was to test the effect of different organo-mineral foliar fertilizers: Zlatno inje, Bioplant Flora, Algaren BZn, Zircon, as well as plant growth regulator Epin Extra, on potential availability of mineral elements (Mg, Fe, Mn and Zn) from grain of three commercial soybean varieties: ZP-015, Nena and Laura (variety lacking in Kunitz trypsin inhibitor). In addition, phytate (Phy) and $\beta$-carotene contents were determined.

Results: ZP-015 achieved the highest P, Mg, Fe, Mn and $\beta$-carotene contents. Laura had the highest Phy level, which might reflect the diminished availability of nutrients from grain. Compared to control, most of the applied fertilizers increased $\beta$-carotene and decreased Mn content in all three soybean varieties. Increase in $\beta$-carotene content was followed by increase in Fe content, mainly in grains with larger weight, as a part of improved yielding potential.

Conclusions: Positive effect of Zircon application was evident on increased grain weight, and $\beta$-carotene and Fe content. These parameters together with the lowest values found for Phy/ $/$-carotene and Phy/Mg ratios may explain the enhanced $\mathrm{Mg}$ and Fe bioavailability. On the other hand, positive effects of Epin Extra were mostly reflected by a decrease of Phy and an increase in Fe and $\mathrm{Mn}$, thus becoming more bio-available. Accordingly, the organo-mineral foliar fertilizers based mainly on phenolic acids (Zircon) and bioregulator (Epin Extra) are to be recommended for soybean fortification.
\end{abstract}

Keywords: Organo-mineral foliar fertilizer; Grain composition; Mineral elements; Phytic phosphorus; Glycine max (L.) Merr

\section{Background}

Nutrition is crucial factor in reduction of hunger, malnutrition and obesity [1]. Human body requires more than 22 mineral elements, which can be provided by adequate diet. On the other hand, nutritional deficiencies (e.g. in iron, zinc, vitamin A) account for almost two-thirds of the childhood deaths worldwide [2]. These deficiencies can be surpassed by increase of mineral nutrients in food through supplementation, food fortification or plant breeding [3,4].

Iron and zinc are considered to be the most important mineral elements in vegetarian diets. Elimination of meat from diet, along with increased intake of whole grain cereals and legumes rich in anti-nutrients, like phytate, significantly decrease $\mathrm{Fe}$ and $\mathrm{Zn}$ absorption [5]. The most prevalent among mineral elements deficiencies is Fe deficiency (anemia), affecting approximately $30 \%$ of the world's

\footnotetext{
* Correspondence: vdragicevic@mrizp.rs

${ }^{1}$ Maize Research Institute, Slobodana Bajića 1, 11185 Zemun Polje, Serbia Full list of author information is available at the end of the article
}

population. $\mathrm{Zn}$ is essential element, involved in the immune system, activation of many enzymes and the growth. Zn deficiency has been detected in cases of inadequate dietary supply, abnormal blood losses or high physiological requirements for growth, as well as during puberty, pregnancy and lactation $[4,5]$. As a part of the antioxidant system of defense in mitochondria, manganese is also essential element for humans and is involved in metabolism, bone development and wound healing. It has been shown that $\mathrm{Mg}$ has protective role against various diseases. However, numerous studies indicated that $\mathrm{Mg}$ concentration in human body is usually insufficient [6]. According to Nielsen [7], low level of Mg has been associated with pathological conditions characterized as a chronic inflammatory stress, being widely associated with obesity, atherosclerosis, hypertension, osteoporosis, diabetes mellitus, and cancer.

According to present knowledge, it is necessary to increase content of mineral nutrients in edible parts of plants. Accumulation of mineral elements in seeds and grains is controlled by a number of processes including 
root-cell uptake, root-shoot transfer, and the ability to deliver these nutrients to developing seeds and grains [8]. Designing of cultivation systems, in order to improve nutrition and health, should become an integral part of goals in modern agriculture. It is mainly concerned to cultivation on poor soils, where micronutrient element enhancement can contribute to increased crop yield. According to Graham et al. [9], probably half of all soils are deficient in micronutrients and even though plant production is not limited, humans and animals whose diets are mainly based on crops can be potentially deficient in essential micronutrients. Incorporation of important mineral elements into soil by fertilizers could be problematic due to their pathway in soil. For instance, Fe from fertilizers could be quickly oxidized and became insoluble in soil, so Fe deficiency is mainly a consequence of Fe deficient soils [9]. Welch [8] reported significant impact of fertilizers containing $\mathrm{N}, \mathrm{P}, \mathrm{K}, \mathrm{S}$ and $\mathrm{Zn}$ on accumulation of nutrients in edible plant products, including grains. Other micronutrient fertilizers were shown to have very small effect on the amount of micronutrients accumulated in edible seeds and grains when applied to soils.

Increased content of mineral elements in crops presents only the first step in making them improved sources of nutrients for humans [10], since not all mineral elements in plant foods are bio-available to humans and animals. Plant food can contain anti-nutrients, which interfere with the absorption of mineral nutrients in humans and animals. The question of bio-availability must be taken into consideration when enrichment of plant food with mineral elements was employed. This also takes into account enhancing substances - promoters (e.g. ascorbic acid, S-containing amino acids, etc.) that promote micronutrient bioavailability and/ or suppress anti-nutrient substances (e.g. phytate, polyphenolics, etc.) that inhibit micronutrient bioavailability $[2,11]$. Thus, it is essential to decrease content of various antinutrients in foods and to increase content of promoters [9].

Phytic acid - Phy (myo-inositol 1,2,3,4,5,6-hexakisphosphate) is the major phosphorus storage compound in grains (accounting for up to $80 \%$ of total $\mathrm{P}$ ) and it can acts as anti-nutritional factor that chelate essential elements including $\mathrm{Ca}, \mathrm{Zn}$ and Fe [12]. As content of phytic acid in diet increases, the intestinal absorption of $\mathrm{Zn}, \mathrm{Fe}$ and other mineral nutrients decreases [12], while the reduction in phytic acid content in food is likely to result in improved $\mathrm{Fe}, \mathrm{Zn}$ and $\mathrm{Mn}$ content $[3,13]$. $\beta$-carotene is considered to be a promoter due to positive effect on mineral nutrients absorption. Lönnerdal [3] stated that $\beta$-carotene can enhance Fe absorption in humans. Luo and Xie [14] found that addition of food rich in $\beta$-carotene or pure $\beta$-carotene, can significantly enhance Fe and $\mathrm{Zn}$ bioavailability from the grains. Moreover, Noh and Koo [15] reported that low $\beta$-carotene absorption is associated with low $\mathrm{Zn}$ intake or slight $\mathrm{Zn}$ deficiency. Different cultivation practices, including macronutrient treatments $(\mathrm{N}, \mathrm{P}$ and $\mathrm{Mg})$, can result in increased concentration of $\beta$-carotene (by $42 \%$ ) and micronutrients in carrots [8].

Soybean is important dietary source of proteins, lipids, minerals, vitamins, fiber and bioactive compounds. However, commonly high levels of phytate in soybean grain could negatively affect its nutritive value. Variability of mineral elements in soybean grain is significant and it also depends on applied cultivation systems $[16,17]$. Since Zn bioavailability from some soya products is low, application of an adequate cultivation system becomes important. However, compared to other plant foods with lower phytate contents, the Fe availability from soya flour and soya isolates is higher.

The aim of this experiment was to investigate the effect of applied foliar fertilizers on mineral nutrients content (i.e. $\mathrm{Mg}, \mathrm{Fe}, \mathrm{Mn}$ and $\mathrm{Zn}$ ), along with contents of phytate as anti-nutritive factor and $\beta$-carotene as promoter, in chosen soybean varieties differing in chemical composition of grain.

\section{Experimental \\ Plant material}

Two commercial soybean varieties with standard grain composition - ZP-015 and Nena, and the variety lacking in Kunitz trypsin inhibitor - Laura, were the objectives of the present study.

\section{Soil}

The field trial was carried out in Zemun Polje $\left(44^{\circ} 52^{\prime} \mathrm{N} 20^{\circ}\right.$ $20^{\prime} E$ ), vicinity of Belgrade, Serbia (in rain-fed conditions). Soil was a slightly calcareous chernozem with $0.0 \%$ coarse, $53.0 \%$ sand, $30.0 \%$ silt, $17.0 \%$ clay, $3.3 \%$ organic matter, $7.0 \mathrm{pH} \mathrm{KCl}$ and $7.17 \mathrm{pH} \mathrm{H}_{2} \mathrm{O}$. The texture was silty clay loam, containing: $37.45 \mathrm{mg} \mathrm{kg}^{-1} \mathrm{~N}, 10.7037 .45 \mathrm{mg} \mathrm{kg}^{-1} \mathrm{P}$, $107.4037 .45 \mathrm{mg} \mathrm{kg}^{-1} \mathrm{~K}, 327.9537 .45 \mathrm{mg} \mathrm{kg}^{-1} \mathrm{Mg}, 0.65$ $37.45 \mathrm{mg} \mathrm{kg}^{-1} \mathrm{Fe}$ and $<0.0237 .45 \mathrm{mg} \mathrm{kg}^{-1} \mathrm{Zn}$ in $0-30 \mathrm{~cm}$ layer, before fertilizer application. A split-plot experimental design in four replications was used in the experiment. Size of elementary plot was $5 \mathrm{~m} \times 5 \mathrm{~m}$.

\section{Foliar fertilizers}

Experimental trial included application of different foliar fertilizers in recommended doses, at the beginning of flowering (first half of June): 1. Zlatno inje (liquid extract of cows manure, with $0.8 \%$ of organic matter, $0.004 \% \mathrm{~N}$ and $0.0004 \% \mathrm{P})$, in amount of $4 \mathrm{~L} \mathrm{ha}^{-1} ; 2$. Bioplant Flora (organic fertilizer with $8 \%$ humic acids, isolated from vermicompost, with $1.0 \% \mathrm{~N}, 1.5 \% \mathrm{P}, 48.35 \mathrm{mg} \mathrm{L}^{-1} \mathrm{Mg}$, $2.41 \mathrm{mg} \mathrm{L}^{-1} \mathrm{~B}, 13.14 \mathrm{mg} \mathrm{L}^{-1} \mathrm{Cu}, 212.8 \mathrm{mg} \mathrm{L}^{-1} \mathrm{Zn}$, $1.64 \mathrm{mg} \mathrm{L}^{-1} \mathrm{Co}, 462 \mathrm{mg} \mathrm{L}^{-1} \mathrm{Mn}, 775.6 \mathrm{mg} \mathrm{L}^{-1} \mathrm{Mo}$ and $500 \mathrm{mg} \mathrm{L}^{-1} \mathrm{Fe}$ ), in the amount of $1 \mathrm{~L} \mathrm{ha}^{-1}$; 3. AlgarenBZn (organic fertilizer based on Ecklonia maxima algae extract with $2 \%$ of $B$ and $3 \%$ of $Z n$ ), in an amount of 
0.834 $\mathrm{L} \mathrm{ha}^{-1} ; 4$. Zircon (extract of medicinal plant Echinacea purpurea $\mathrm{L}$., that contains a mixture of $0.1 \mathrm{~g} \mathrm{~L}^{-1}$ of phenolic acids: 3,4-dihydroxycinnamic (caffeic) acid (IUPAC: 3-(3, 4-dihydroxyphenyl)-2-propenoic acid; CAS No 331-95-5), chlorogenic acid (IUPAC: $(1 S, 3 R, 4 R, 5 R)-3-$ $\{[(2 Z)-3$-(3,4-dihydroxyphenyl)prop-2-enoyl $]$ oxy $\}-1,4,5$ trihydroxycyclohexanecarboxylic acid; CAS No 327-97-9), cichoric acid (IUPAC: $(2 R, 3 R)-2,3-b i s\{[(E)-3-(3,4-d i h y d r o x y-$ phenyl)prop-2-enoyl]oxy\}butanedioic acid; CAS No 32797-9), as active ingredients identical to Echinacea purpurea L. plant extract), in the amount of $0.12 \mathrm{~L} \mathrm{ha}^{-1} ; 5$. plant growth regulator Epin Extra (based on $0.025 \mathrm{~g} \mathrm{~L}^{-1}$ of 24epibrassinolide (IUPAC: (22R 23R 24S)-2 $\alpha, 3 \alpha, 22,23$ tetra hydroxy-24-metyl $5 \alpha$-holestan-6-on; CAS No 72962-43-7), in the amount of $0.136 \mathrm{~L} \mathrm{ha}^{-1}$. All these organo-mineral fertilizers were applied with a dose of $400 \mathrm{~L} \mathrm{ha}^{-1}$ of water.

\section{Methods}

\section{Chemical analyses}

After harvesting, 1,000 grain weight was measured and contents of different metabolites in soybean grain were determined. Contents of inorganic phosphorus $\left(\mathrm{P}_{\mathrm{i}}\right)$ and phytic phosphorus $\left(\mathrm{P}_{\text {phy }}\right)$ were determined colorimetrically after extraction with $5 \%$ trichloroacetic acid, by method of Dragicevic et al. [18]: $\mathrm{P}_{\text {phy }}$ was determined with Wade reagent and $P_{i}$ with vanado-molybdate reagent. $\beta$-carotene content was also determined colorimetrically, after extraction with saturated butanol [19]. Content of total phosphorus $\left(\mathrm{P}_{\text {tot }}\right)$ was analysed with vanado-molybdate colorimetric method after wet digestion with $\mathrm{HClO}_{4}+$ $\mathrm{HNO}_{3}$, by method of Pollman [20]. The same digested samples were used for determination of mineral elements (i.e. Fe, Mn, Zn, and Mg) by Inductively Coupled Plasma Optical Emission Spectrometry.

\section{Statistical analysis}

All analyses were performed in four replicates $(n=4)$ and the results were presented as mean \pm standard deviation (SD). The differences among soybean varieties and applied treatments, based on mean values of observed parameters, were evaluated by using Principle Component Analysis (PCA). Statistical analysis was performed by SPSS 15.0 for Windows Evaluation version. Correlation analyses were performed using Pearson's correlation coefficient.

\section{Results and Discussion}

Grain weight and chemical composition of the grain

Results presented in Table 1 indicated that the greatest average 1,000 grain weight was achieved by the Laura

Table 1 The effect of different foliar fertilizers on chemical composition of grain in three soybean varieties

\begin{tabular}{|c|c|c|c|c|c|c|}
\hline & Treatment & 1,000 grain weight $(\mathrm{g})$ & $P_{\text {tot }}^{* *}\left(g_{\text { kg }}^{-1}\right)$ & $P_{i}\left(g_{~ k g}{ }^{-1}\right)$ & $P_{\text {phy }}\left(\mathrm{g} \mathrm{kg}^{-1}\right)$ & $\beta$-carotene $\left(\mathrm{mg} \mathrm{kg}^{-1}\right)$ \\
\hline \multirow[t]{7}{*}{ ZP-015 } & Control & $178.1 \pm 12.1^{*}$ & $16.12 \pm 0.08$ & $0.30 \pm 0.01$ & $12.88 \pm 0.23$ & $13.53 \pm 0.04$ \\
\hline & Zlatno inje & $198.2 \pm 6.7$ & $16.87 \pm 0.00$ & $0.38 \pm 0.03$ & $12.71 \pm 0.02$ & $11.95 \pm 0.19$ \\
\hline & Epin Extra & $180.9 \pm 9.4$ & $16.53 \pm 0.03$ & $0.30 \pm 0.03$ & $12.14 \pm 0.16$ & $13.92 \pm 0.17$ \\
\hline & Zircon & $174.2 \pm 6.9$ & $16.25 \pm 0.03$ & $0.34 \pm 0.03$ & $12.06 \pm 0.05$ & $18.73 \pm 0.09$ \\
\hline & Bioplant Flora & $182.7 \pm 10.5$ & $16.96 \pm 0.11$ & $0.38 \pm 0.01$ & $12.59 \pm 0.35$ & $15.96 \pm 0.06$ \\
\hline & AlgarenBZn & $176.4 \pm 11.9$ & $17.12 \pm 0.03$ & $0.46 \pm 0.00$ & $12.61 \pm 0.20$ & $14.87 \pm 0.09$ \\
\hline & Average & $181.7 \pm 9.6$ & $16.64 \pm 0.04$ & $0.36 \pm 0.02$ & $12.50 \pm 0.17$ & $14.83 \pm 0.11$ \\
\hline \multirow[t]{7}{*}{ Nena } & Control & $171.9 \pm 13.5$ & $13.69 \pm 0.08$ & $0.49 \pm 0.02$ & $13.49 \pm 0.03$ & $14.84 \pm 0.11$ \\
\hline & Zlatno inje & $170.4 \pm 6.0$ & $14.27 \pm 0.11$ & $0.47 \pm 0.00$ & $12.50 \pm 0.36$ & $10.94 \pm 0.17$ \\
\hline & Epin Extra & $172.9 \pm 8.7$ & $15.42 \pm 0.11$ & $0.47 \pm 0.00$ & $12.33 \pm 0.40$ & $14.08 \pm 0.11$ \\
\hline & Zircon & $191.0 \pm 7.0$ & $14.40 \pm 0.00$ & $0.29 \pm 0.01$ & $12.70 \pm 0.16$ & $12.40 \pm 0.13$ \\
\hline & Bioplant Flora & $172.6 \pm 8.8$ & $14.38 \pm 0.08$ & $0.31 \pm 0.02$ & $12.43 \pm 0.14$ & $15.78 \pm 0.19$ \\
\hline & AlgarenBZn & $171.1 \pm 8.2$ & $14.97 \pm 0.03$ & $0.32 \pm 0.02$ & $12.95 \pm 0.25$ & $12.61 \pm 0.06$ \\
\hline & Average & $175.0 \pm 8.7$ & $14.52 \pm 0.07$ & $0.39 \pm 0.01$ & $12.73 \pm 0.22$ & $13.44 \pm 0.13$ \\
\hline \multirow[t]{7}{*}{ Laura } & Control & $207.0 \pm 11.4$ & $14.68 \pm 0.13$ & $0.46 \pm 0.00$ & $12.46 \pm 0.00$ & $10.99 \pm 0.11$ \\
\hline & Zlatno inje & $194.9 \pm 6.7$ & $14.29 \pm 0.08$ & $0.41 \pm 0.03$ & $12.43 \pm 0.20$ & $12.22 \pm 0.11$ \\
\hline & Epin Extra & $197.5 \pm 8.7$ & $14.79 \pm 0.00$ & $0.47 \pm 0.00$ & $12.18 \pm 0.00$ & $11.44 \pm 0.02$ \\
\hline & Zircon & $206.4 \pm 5.5$ & $14.13 \pm 0.24$ & $0.46 \pm 0.00$ & $11.93 \pm 0.01$ & $12.93 \pm 0.06$ \\
\hline & Bioplant Flora & $208.1 \pm 10.2$ & $13.67 \pm 0.19$ & $0.49 \pm 0.00$ & $12.36 \pm 0.01$ & $10.33 \pm 0.09$ \\
\hline & AlgarenBZn & $207.9 \pm 8.8$ & $14.08 \pm 0.03$ & $0.48 \pm 0.00$ & $12.42 \pm 0.06$ & $11.99 \pm 0.21$ \\
\hline & Average & $203.6 \pm 8.5$ & $14.27 \pm 0.11$ & $0.46 \pm 0.01$ & $12.29 \pm 0.05$ & $11.65 \pm 0.10$ \\
\hline
\end{tabular}


variety (25.25 g larger than ZP-015 and Nena). Sudarić et al. [21] indicated that 1,000 grain weight is a very important yielding parameter, so that its increase should be considered as the main target for any applied cultivation measure. Compared to control, an average 1,000 grain weight increase of $4.49 \mathrm{~g}$ was achieved in Zircon treatment, for all three genotypes. Concerning the individual effect of each applied fertilizer, Zlatno inje increased the 1,000 grain weight mainly in ZP-015, while Epin Extra did so in Nena, and Bioplant Flora in the Laura variety.

The largest average $\mathrm{P}_{\text {tot }}$ was recorded in ZP-015 (2.02 $\mathrm{g} \mathrm{kg}^{-1}$ greater than Nena and Laura), as presented in Table 1. A significant effect of fertilizers on increased $\mathrm{P}_{\text {tot }}$ content was obtained by Algaren BZn, mainly exhibited in grains of ZP-015 and Nena, while the $\mathrm{P}_{\text {tot }}$ content increase in Laura grain was achieved only by applying Epin Extra. It is known that the majority of $\mathrm{P}$ pool in soybean grain is present as $\mathrm{P}_{\mathrm{phy}}$, while the minor part is due to inorganic $\mathrm{P}_{\mathrm{i}}$. It is interesting to underline that in grain of ZP-015, only $75 \%$ of average $\mathrm{P}_{\text {tot }}$ consisted of $\mathrm{P}_{\text {phy }}$, while it was $86-88 \%$ in other two varieties. Nevertheless, such decreased $\mathrm{P}_{\text {phy }}$ in ZP-015 did not determine an increase of $\mathrm{P}_{\mathrm{i}}$, that is the main source of available $\mathrm{P}$ from grains. Hence this genotype may be considered for further $\mathrm{P}_{\text {phy }}$ decrease by breeding $[3,22]$.
The largest average content of $\mathrm{P}_{\text {phy }}$ was found in Nena grain, with slight variations of $\mathrm{P}_{\mathrm{phy}}$ and $\mathrm{P}_{\mathrm{i}}$ content in response to the applied foliar fertilizers. Bioplant Flora and Algaren $\mathrm{BZn}$ induced slight increase in $\mathrm{P}_{\mathrm{i}}$ content in grain of ZP-015 and Laura, while Epin Extra and Zircon decreased $\mathrm{P}_{\mathrm{phy}}$ in grains of all three varieties. It is also noticed that the largest average $\mathrm{P}_{\text {phy }}$ was found in control. In relation to $P_{p h y}, \beta$-carotene variation was to a larger extent, with the largest average values observed in ZP-015 grain. Among the applied fertilizers, the greatest increase in $\beta$-carotene content was achieved by the Zircon application on ZP-015 and Laura, and by Bioplant Flora on Nena grain.

Investigated soybean varieties differed to a larger extent in mineral composition of their grain. The largest average $\mathrm{Mg}, \mathrm{Fe}$ and Mn content was observed in ZP-015 grains, while the relatively greatest average $\mathrm{Zn}$ content was found in the Laura grains (Table 2). In parallel with $\mathrm{P}_{\text {phy }}$ decrease (Table 1), foliar fertilizers mainly exhibited a positive impact on the increase of mineral nutrients content. This could be positively related to a larger Fe, $\mathrm{Zn}$ and $\mathrm{Mn}$ status [3,13]. Compared to control and for all three genotypes, average increase for $\mathrm{Mg}$ and $\mathrm{Zn}$ contents (by $3 \%$ and 20\%, respectively) was found under Bioplant Flora, for Fe content (7\%) under Zircon, and

Table 2 The effect of different foliar fertilizers on mineral element contents in soybeans grain

\begin{tabular}{|c|c|c|c|c|c|c|c|c|c|c|c|c|c|}
\hline \multirow{2}{*}{$\overline{Z P-015}$} & \multirow{2}{*}{$\begin{array}{c}\text { Treatment } \\
\text { Control }\end{array}$} & \multicolumn{3}{|c|}{$\mathrm{Mg}\left(\mathrm{mg} \mathrm{kg}^{-1}\right)$} & \multicolumn{3}{|c|}{$\mathrm{Fe}\left(\mathrm{mg} \mathrm{kg}^{-1}\right)$} & \multicolumn{3}{|c|}{$\mathrm{Mn}\left(\mathrm{mg} \mathrm{kg}^{-1}\right)$} & \multicolumn{3}{|c|}{$\mathrm{Zn}\left(\mathrm{mg} \mathrm{kg}^{-1}\right)$} \\
\hline & & 2284.4 & \pm & $48.6^{*}$ & 65.66 & \pm & 0.49 & 29.66 & \pm & 1.37 & 34.41 & \pm & 2.78 \\
\hline & Zlatno inje & 2331.3 & \pm & 0.0 & 70.13 & \pm & 0.18 & 29.97 & \pm & 1.46 & 45.41 & \pm & 3.23 \\
\hline & Epin Extra & 2459.4 & \pm & 4.4 & 71.47 & \pm & 0.84 & 31.53 & \pm & 0.31 & 36.00 & \pm & 4.15 \\
\hline & Zircon & 2215.6 & \pm & 39.8 & 78.41 & \pm & 0.35 & 25.78 & \pm & 0.57 & 48.13 & \pm & 2.08 \\
\hline & Bioplant Flora & 2371.9 & \pm & 30.9 & 68.69 & \pm & 1.99 & 26.75 & \pm & 0.35 & 44.91 & \pm & 1.15 \\
\hline & AlgarenBZn & 2356.3 & \pm & 35.4 & 67.91 & \pm & 0.66 & 28.56 & \pm & 1.33 & 38.13 & \pm & 2.12 \\
\hline & Average & 2336.5 & \pm & 26.5 & 70.38 & \pm & 0.75 & 28.71 & \pm & 0.90 & 41.16 & \pm & 2.59 \\
\hline \multirow[t]{7}{*}{ Nena } & Control & 2221.9 & \pm & 13.3 & 57.34 & \pm & 0.40 & 26.00 & \pm & 0.00 & 37.44 & \pm & 2.92 \\
\hline & Zlatno inje & 2106.3 & \pm & 35.4 & 60.75 & \pm & 2.25 & 23.56 & \pm & 1.02 & 35.63 & \pm & 0.09 \\
\hline & Epin Extra & 2162.5 & \pm & 17.7 & 64.34 & \pm & 0.80 & 26.28 & \pm & 0.53 & 32.09 & \pm & 0.13 \\
\hline & Zircon & 2321.9 & \pm & 39.8 & 62.31 & \pm & 0.62 & 23.78 & \pm & 0.49 & 35.09 & \pm & 2.34 \\
\hline & Bioplant Flora & 2320.9 & \pm & 39.8 & 63.16 & \pm & 0.75 & 22.97 & \pm & 1.64 & 40.38 & \pm & 2.65 \\
\hline & AlgarenBZn & 2181.3 & \pm & 0.0 & 58.81 & \pm & 0.62 & 21.94 & \pm & 0.09 & 30.56 & \pm & 3.36 \\
\hline & Average & 2219.1 & \pm & 24.3 & 61.12 & \pm & 0.91 & 24.09 & \pm & 0.63 & 35.20 & \pm & 1.92 \\
\hline \multirow[t]{7}{*}{ Laura } & Control & 2172.5 & \pm & 25.6 & 60.09 & \pm & 1.37 & 26.59 & \pm & 1.02 & 42.84 & \pm & 2.52 \\
\hline & Zlatno inje & 2215.9 & \pm & 13.3 & 66.13 & \pm & 0.22 & 27.31 & \pm & 0.75 & 59.72 & \pm & 8.62 \\
\hline & Epin Extra & 2234.7 & \pm & 45.1 & 59.34 & \pm & 1.06 & 25.81 & \pm & 0.71 & 56.59 & \pm & 11.62 \\
\hline & Zircon & 2138.1 & \pm & 25.2 & 57.13 & \pm & 0.62 & 24.78 & \pm & 0.49 & 54.81 & \pm & 4.95 \\
\hline & Bioplant Flora & 2177.8 & \pm & 85.3 & 56.72 & \pm & 3.58 & 25.38 & \pm & 1.15 & 57.44 & \pm & 1.94 \\
\hline & AlgarenBZn & 2090.6 & \pm & 19.0 & 58.00 & \pm & 0.88 & 20.47 & \pm & 0.09 & 45.03 & \pm & 3.31 \\
\hline & Average & 2187.8 & \pm & 35.6 & 59.57 & \pm & 1.29 & 25.06 & \pm & 0.70 & 52.74 & \pm & 5.49 \\
\hline
\end{tabular}

*The results are represented as mean \pm SD (standard deviation) in four replicates. 
for $\mathrm{Mn}$ content (only 2\% of its increase) under Epin Extra treatment. Zlatno inje increased $\mathrm{Fe}, \mathrm{Mn}$ and $\mathrm{Zn}$ content mainly in Laura grain, while Epin Extra showed the greatest impact on Mg increase in ZP-015 and Laura grains, and on Mn increase in ZP-015 and Nena grain, as well as on Fe increase in Nena grain. Zircon was the most efficient for Fe and $\mathrm{Zn}$ increase in ZP-015 and for $\mathrm{Mg}$ increase in Nena grains. Among the applied fertilizers, only Bioplant Flora was responsible for Zn content increase in Nena grains.

\section{Availability of mineral nutrients}

Variations in ratio between phytate (Phy) and $\beta$-carotene may indicate possible availability of nutrients $[12,23]$. This trait is an important parameter for the characterisation of the investigated genotypes. From this point, ZP015 could be considered as a favourable variety for breeding towards an improved nutritive quality, having the lowest ratios for Phy/Mg, Phy/Fe and Phy/Mn in the control (Table 3). This indicates an additional quality of this genotype for a possible increase of mineral nutrients availability, under application of organo-mineral foliar fertilizers. This is important, since Luo and Xie [14] and Hess et al. [24] found that food rich in $\beta$-carotene can significantly enhance $\mathrm{Fe}$ and $\mathrm{Zn}$ bioavailability from grain, while either low phytate level or its degradation may enhance Mn availability [16]. Besides ZP-015, Laura variety was characterised by the lowest $\mathrm{P}_{\text {phy }} / \mathrm{P}_{\mathrm{i}}$ and Phy/ $\mathrm{Zn}$ ratios. This may become a possible indicator for further $\mathrm{P}_{\text {phy }}$ decrease during breeding $[3,22]$, although further research is required. When the individual impact of each foliar fertilizer on all three genotypes was considered, Zlatno inje decreased $\mathrm{P}_{\text {phy }} / \mathrm{P}_{\mathrm{i}}$ and Phy/Mn ratios to the largest extent, while Zircon was the most prominent for Phy/ $/$-carotene, Phy/Mg and Phy/Zn ratios. Epin Extra was mostly efficient in Phy/Fe decrease. Since Fe and $\mathrm{Zn}$ deficiencies are common worldwide [5], it is very important that Zircon and Epin Extra, that are organomineral foliar fertilizers which are primarily dedicated to fortification, increased average Fe and $\mathrm{Zn}$ content in soybean grains. Furthermore, each fertilizer had a specific site of action: Zircon and Epin Extra decreased $\mathrm{P}_{\mathrm{phy}} / \beta-$ carotene, Phy $/ \mathrm{Mg}$, Phy $/ \mathrm{Fe}$ and $\mathrm{Phy} / \mathrm{Zn}$ ratios in grain of ZP-015, while Bioplant Flora and Epin Extra decreased $\mathrm{P}_{\text {phy }} / \beta$-carotene, Phy/Mg and Phy/Fe ratios in Nena grain. In Laura variety, application of Zlatno inje induced a decrease in $\mathrm{P}_{\mathrm{phy}} / \beta$-carotene, Phy/Fe, Phy/Mn and Phy/Zn ratios.

Different responses of the examined soybean varieties to the applied treatments can be better visualised by PC

Table 3 The effect of different foliar fertilizers on investigated ratios in grain of three soybean varieties

\begin{tabular}{|c|c|c|c|c|c|c|c|}
\hline & Treatment & $\mathrm{P}_{\text {phy }} / \mathrm{P}_{\mathrm{i}}^{*}$ & Phy/ß-carot & Phy/Mg & Phy/Fe & Phy/Mn & Phy/Zn \\
\hline \multirow[t]{7}{*}{ ZP-015 } & Control & 43.17 & 774.3 & 0.48 & 16.60 & 36.74 & 31.67 \\
\hline & Zlatno inje & 33.15 & 865.5 & 0.46 & 15.34 & 35.90 & 23.70 \\
\hline & Epin Extra & 40.63 & 709.2 & 0.42 & 14.37 & 32.57 & 28.53 \\
\hline & Zircon & 35.44 & 523.6 & 0.46 & 13.01 & 39.57 & 21.20 \\
\hline & Bioplant Flora & 33.22 & 641.6 & 0.45 & 15.51 & 39.83 & 23.72 \\
\hline & AlgarenBZn & 27.61 & 689.9 & 0.45 & 15.71 & 37.36 & 27.99 \\
\hline & Average & 34.77 & 685.7 & 0.45 & 15.03 & 36.84 & 25.69 \\
\hline \multirow[t]{7}{*}{ Nena } & Control & 27.24 & 739.4 & 0.51 & 19.90 & 43.89 & 30.48 \\
\hline & Zlatno inje & 26.87 & 929.5 & 0.50 & 17.42 & 44.91 & 29.70 \\
\hline & Epin Extra & 26.41 & 712.2 & 0.48 & 16.22 & 39.70 & 32.51 \\
\hline & Zircon & 44.42 & 833.1 & 0.46 & 16.88 & 45.19 & 29.98 \\
\hline & Bioplant Flora & 40.19 & 640.8 & 0.45 & 17.02 & 46.79 & 26.62 \\
\hline & AlgarenBZn & 40.14 & 835.0 & 0.50 & 18.63 & 49.94 & 35.85 \\
\hline & Average & 32.58 & 770.5 & 0.49 & 17.63 & 44.73 & 30.61 \\
\hline \multirow[t]{7}{*}{ Laura } & Control & 27.25 & 922.2 & 0.49 & 17.54 & 39.64 & 24.60 \\
\hline & Zlatno inje & 30.27 & 827.1 & 0.50 & 15.90 & 38.50 & 17.61 \\
\hline & Epin Extra & 25.71 & 865.8 & 0.48 & 17.36 & 39.92 & 18.21 \\
\hline & Zircon & 25.78 & 750.5 & 0.45 & 17.67 & 40.73 & 18.41 \\
\hline & Bioplant Flora & 25.31 & 973.9 & 0.48 & 18.45 & 41.23 & 18.22 \\
\hline & AlgarenBZn & 26.14 & 842.1 & 0.47 & 18.12 & 51.34 & 23.34 \\
\hline & Average & 26.66 & 858.5 & 0.48 & 17.47 & 41.52 & 19.73 \\
\hline
\end{tabular}

*Ratios: $\mathrm{P}_{\text {phy }} / \mathrm{P}_{\mathrm{i}}$, phytic and inorganic $\mathrm{P}$; Phy/ $\beta$-carot, phytate and $\beta$-carotene; Phy/Mg, Phy/Fe, Phy/Mn, Phy/Zn, phytate and mineral nutrients. 


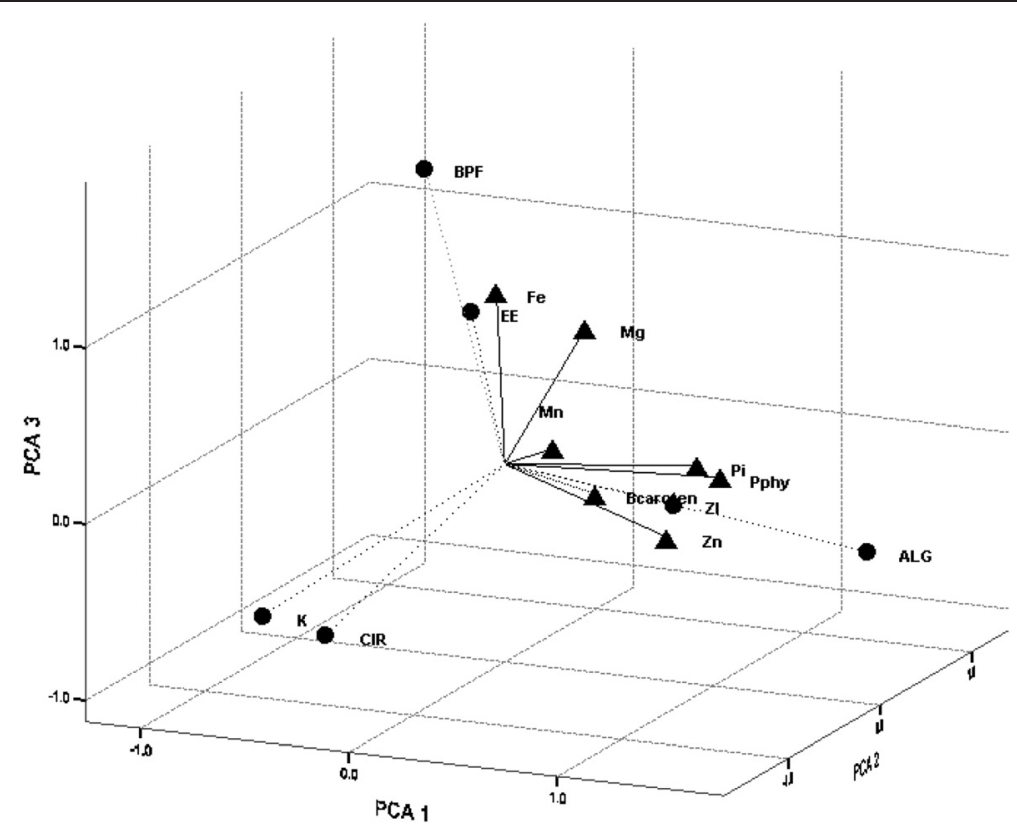

Figure 1 Principal component analysis (PCA) for chemical composition of grain in ZP-015 variety $\left(P_{\text {phy, }}\right.$ phytic phosphorus; $P_{i}$, inorganic phosphorus, K, control; Zl, Zlatno inje; EE, Epin Extra; CIR, Zircon; BPF, Bioplant Flora; ALG, Algaren BZn).

analysis. In grains of ZP-015, results indicated the Epin Extra treatment as the most efficient for Fe and Mg content increase (Figure 1). Positive effects of Zlatno Inje and Algaren BZn were shown mostly on the increase of $\mathrm{P}_{\mathrm{i}}$ and $\mathrm{P}_{\text {phy }}$ content, and, partially, on $\beta$-carotene and $\mathrm{Zn}$ content. In Nena's grain, a most pronounced increase was found in $\beta$-carotene, $\mathrm{Mg}$ and Fe contents under the application of the Zircon treatment, thus positively affecting the bioavailability of these mineral elements (Figure 2). However, application of investigated foliar fertilizers did not demonstrate the expected positive effect on an improved content and bioavailability of $\mathrm{Zn}$. In Laura's grain, Epin Extra was the most efficient foliar fertilizer, leading to an increase in $\mathrm{P}_{\mathrm{phy}}, \mathrm{Fe}$ and $\mathrm{Zn}$

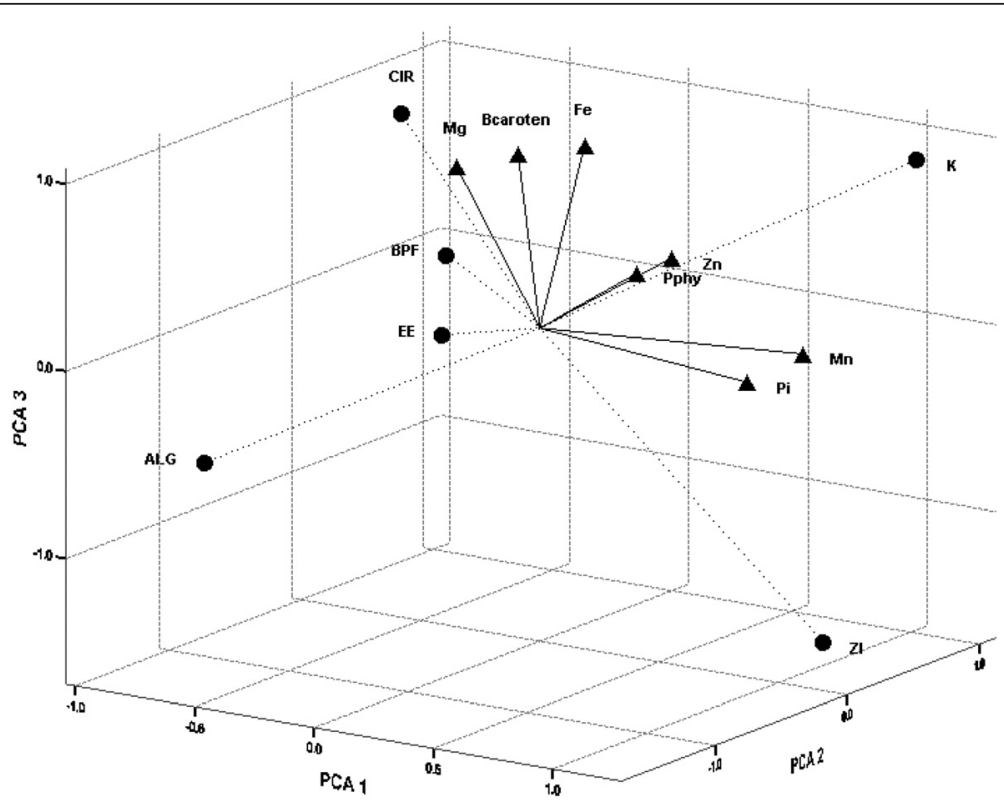

Figure 2 Principal component analysis (PCA) for chemical composition of grain in Nena variety $\left(P_{\text {phy, }}\right.$ phytic phosphorus; $P_{i}$, inorganic phosphorus, K, control; ZI, Zlatno inje; EE, Epin Extra; CIR, Zircon; BPF, Bioplant Flora; ALG, Algaren BZn). 


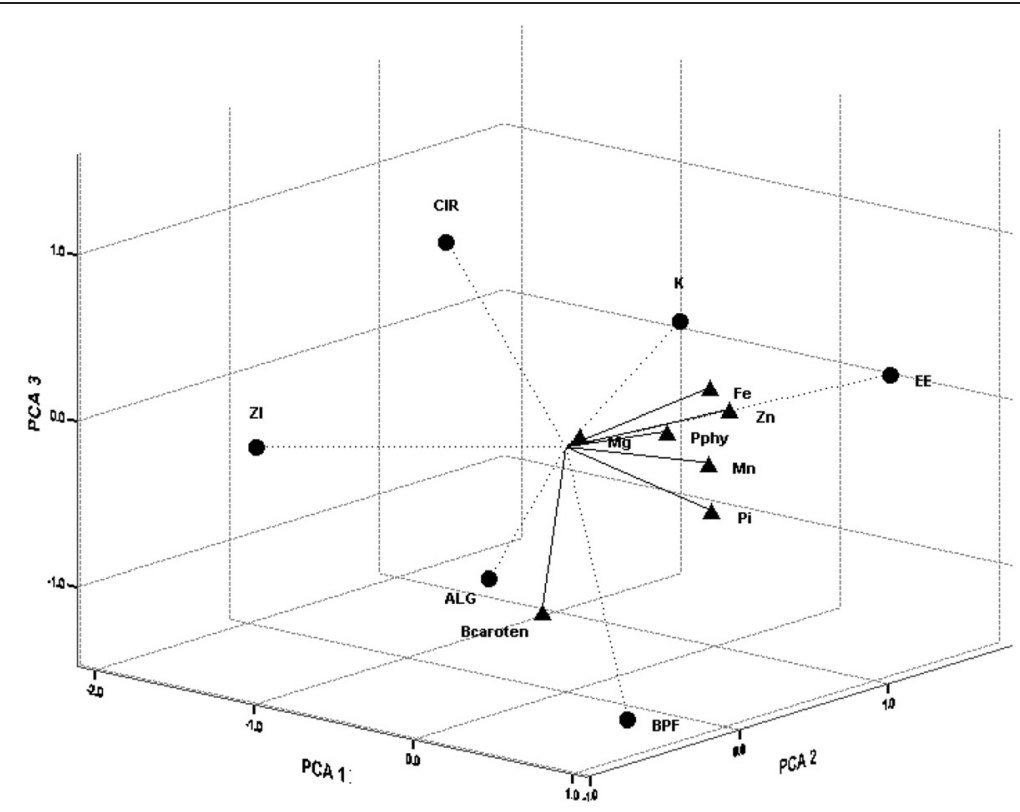

Figure 3 Principal component analysis (PCA) for chemical composition of grain in Laura variety $\left(P_{\text {phy, }}\right.$ phytic phosphorus; $P_{i}$, inorganic phosphorus, K, control; ZI, Zlatno inje; EE, Epin Extra; CIR, Zircon; BPF, Bioplant Flora; ALG, Algaren BZn).

content, and, by a lower extent, to that in $\mathrm{P}_{\mathrm{i}}$ and $\mathrm{Mn}$ content, whereas treatment with Algaren BZn showed a $\beta$-carotene content increase (Figure 3). Such results suggest that measures to increase mineral nutrients in soybean grain (such as fortification) were related to alterations of $\mathrm{P}_{\text {phy }}$ and $\beta$-carotene. Moreover, results obtained on maize and beans did not support a lower Fe availability from grains linked to slightly larger phytate content, while a significant effect on Fe availability is commonly atributed to promoting factors [25].

Interactions between examined parameters may be important for understanding potential availability of mineral elements. Results presented in Table 4 indicated that a large grain weight correlated significantly and positively with $\mathrm{Zn}$ content but negatively with $\beta$ carotene. Conversly, significant and negative correlation between $\mathrm{P}_{\text {phy }}$ and $\mathrm{Zn}$ may be directly related to an improved $\mathrm{Zn}$ availability, as shown by the results of Lönnerdal [3] and Underwood and Suttle [13], who ascertained that any reduction in phytic acid content in food is likely to result in improved Fe, $\mathrm{Zn}$ and $\mathrm{Mn}$ status. Improved Fe availability could be supported by its significant and positive correlation with $\beta$-carotene. Significant and positive correlation between $\mathrm{Mg}, \mathrm{Fe}$ and $\mathrm{Mn}$, as well as with $\mathrm{P}_{\text {tot }}$ indicates that an improved mineral nutrition under application of organo-mineral foliar fertilizers, may increase the concentration of individual elements in grain, althogh their availability may be still questionable. Opposite to $\mathrm{Mg}, \mathrm{Fe}$ and $\mathrm{Mn}$, the $\mathrm{Zn}$ increase was primarily related to a yield parameter, such as the 1,000 grains weight, that was mainly increased by Bioplant Flora (Table 1).

Table 4 Correlations between investigated parameters in grain of three soybean varieties

\begin{tabular}{|c|c|c|c|c|c|c|c|c|}
\hline & 1,000 grain weight & $P_{\text {tot }}^{* *}$ & $P_{i}$ & $P_{\text {phy }}$ & $\beta$-carot. & $\mathrm{Mg}$ & $\mathrm{Fe}$ & $\mathrm{Mn}$ \\
\hline$P_{\text {tot }}$ & $-0.310^{*}$ & & & & & & & \\
\hline$P_{i}$ & 0.367 & -0.394 & & & & & & \\
\hline$P_{\text {phy }}$ & -0.370 & -0.063 & -0.052 & & & & & \\
\hline$\beta$-carot. & $-0.596^{*}$ & $0.475^{*}$ & -0.377 & -0.016 & & & & \\
\hline Mg & -0.264 & $0.674^{*}$ & $-0.601^{*}$ & 0.091 & 0.389 & & & \\
\hline $\mathrm{Fe}$ & -0.359 & $0.801^{*}$ & $-0.513^{*}$ & -0.233 & $0.654^{*}$ & $0.581^{*}$ & & \\
\hline $\mathrm{Mn}$ & -0.066 & $0.660^{*}$ & -0.179 & -0.015 & 0.135 & $0.651^{*}$ & $0.571^{*}$ & \\
\hline $\mathrm{Zn}$ & $0.683^{*}$ & -0.256 & 0.389 & $-0.494^{*}$ & -0.203 & -0.204 & -0.082 & 0.006 \\
\hline
\end{tabular}

${ }^{*}$ Correlation is significant at 0.05 level.

${ }^{*} \mathrm{P}_{\mathrm{i}}$, inorganic $\mathrm{P} ; \mathrm{P}_{\text {phy, }}$ phytic $\mathrm{P}$; $\mathrm{P}_{\text {tot }}$, total $\mathrm{P}$. 


\section{Conclusions}

Our findings showed that ZP-015 can be generally considered as a favourable variety for increased bioavailability of $\mathrm{Mg}, \mathrm{Fe}$ and $\mathrm{Mn}$ (due to the lowest ratios of Phy/ $\mathrm{Mg}, \mathrm{Phy} / \mathrm{Fe}$ and Phy/Mn found in control samples). Moreover, in all varieties, an improvement in grain yielding potential and grain quality was achieved through foliar application of organo-mineral fertilizers. Positive effect of Zircon application was evident on the increased grain weight, and $\beta$-carotene and Fe content. The latter which may, along with the lowest values obtained for $\mathrm{Phy} / \beta$-carotene and $\mathrm{Phy} / \mathrm{Mg}$ ratios, have determined an increase in $\mathrm{Mg}$ and Fe bio-availability, mainly for Nena grain. On the other hand, positive effect of Epin Extra was observed mostly because of both Phy decrease and $\mathrm{Fe}$ and $\mathrm{Mn}$ increase, thus contributing to their increased bio-availability. Accordingly, organo-mineral foliar fertilizers based mainly on phenolic acids (Zircon) and bioregulators (Epin Extra) should be recommended to be used for soybean fortification.

\section{Competing interests}

The authors declare that they have no competing interests.

\section{Authors' contributions}

Bogdan Nikolić and Vesna Dragičević designed the research. Bogdan Nikolić, Vesna Dragičević, Hadi Waisi, Igor Spasojević and Vesna Perić performed field trials. Milovan Stojiljković, Vesna Dragičević and Sanja Đurović performed chemical analyses. Vesna Dragičević and Igor Spasojević analyzed the data. Vesna Dragičević and Bogdan Nikolić wrote the paper. All authors read and approved the final manuscript

\section{Acknowledgement}

This work was supported by Project TR31037 from the Ministry of Education, Science and Technological Development, Republic of Serbia.

\section{Author details}

'Maize Research Institute, Slobodana Bajića 1, 11185 Zemun Polje, Serbia. ${ }^{2}$ Institute for Plant Protection and Environment, Teodora Drajzera 9, 11000 Belgrade, Serbia. ${ }^{3}$ Institute for the Development of Water Resources, "Jaroslav Černi", Jaroslava Černog 80, 11226 Belgrade, Serbia. ${ }^{4}$ Vinca Institute of Nuclear Sciences, 52211001 Belgrade, Serbia.

Received: 22 September 2014 Accepted: 7 February 2015

Published online: 28 April 2015

\section{References}

1. Campanini B (Ed) (2002) The World Health report (2002) Reducing Risks. Promoting Healthily Life. World Health organization, Geneva, Switzerland, pp 1-168

2. Welch RM, Graham RD (2004) Breeding for micronutrients in staple food crops from a human nutrition perspective. J Exp Bot 55(396):353-364

3. Lönnerdal B (2003) Genetically modified plants for improved trace element nutrition. J Nutr 133(5):1490S-1493S

4. White PJ, Broadley MR (2005) Biofortifying crops with essential mineral elements. Trends Plant Sci 10(12):586-593

5. Hunt JR (2003) Bioavailability of iron, zinc, and other trace minerals from vegetarian diets. Am J Clin Nutr 78(suppl):633S-6395

6. Vormann J (2003) Magnesium: nutrition and metabolism. Molecul Aspects Med 24(1-3):27-37

7. Nielsen FH (2010) Magnesium, inflammation, and obesity in chronic disease. Nutrition Rev 68(6):333-340

8. Welch RM (2003) Farming for Nutritious Foods: Agricultural Technologies for improved Human Health. IFA-FAO Agriculture Conference "Global Food Security and the Role of Sustainable Fertilization" Rome, Italy, pp.1-24
9. Graham RD, Welch RM, Saunders DA, Ortiz-Monasterio I, Bouis HE, Bonierbale M, et al. (2007) Nutritious Subsistence Food Systems. Advances Agron 92:1-74

10. Welch RM, Graham RD (1999) A new paradigm for world agriculture: meeting human needs - Productive, sustainable, nutritious. Field Crops Res 60:1-10

11. Hurrell RF (2003) Influence of vegetable protein sources on trace element and mineral bioavailability. J Nutr 133:2973S-2977S

12. Walter Lopez H, Leenhardt F, Coudray C, Remesy C (2002) Minerals and phytic acid interactions: is it a real problem for human nutrition? Internat $J$ Food Sci Technol 37:727-739

13. Underwood EJ, Suttle NF (1999) Manganese. The Mineral Nutrition of Livestock, CABI Publishing, USA, In, pp 397-420

14. Luo YW, Xie WH (2012) Effects of vegetables on iron and zinc availability in cereals and legumes. Internat Food Res J 19(2):455-459

15. Noh SK, Koo SI (2003) Low zinc intake decreases the lymphatic output of retinol in rats infused intraduodenally with beta-carotene. J Nutr Biochem 14(3):147-53

16. Dragicevic V, Oljaca S, Dolijanovic Z, Stojiljkovic M, Spasojevic I, Nisavic M (2013) Effect of intercropping systems and fertilizers on maize and soybean grain composition. Cost Action FA0905 Mineral Improved Crop Production for Healthy Food and Feed, 4TH Annual Conference. Norwegian University of Life Sciences, Aas, Book of Abstracts, p 31

17. Jaffe G (1981) Phytic acid in soybeans. J Am Oil Chem Soc 58(3):493-495

18. Dragičević V, Sredojević S, Perić V, Nišavić A, Srebrić M (2011) Validation study of a rapid colorimetric method for the determination of phytic acid and norganic phosphorus from grains. Acta Period Technol 42:11-21

19. American Association of Cereal Chemists Method (1995) Approved Methods of the AACC. The association: St. Paul, Minnesota, USA, AACC Method, pp 14-50

20. Pollman RM (1991) Atomic absortion spectrophotometric determination of calcium and magnesium and colorimetric determination of phosphorius in cheese. Collaborative study. J Assoc Official Analytic Chem 74(1):27-30

21. Sudarić A, Vratarić M, Duvnjak T (2002) Quantitative genetic analysis of yield components and grain yield for soybean cultivars. Poljoprivreda (Osijek) 8 (2):11-16

22. Dragicevic V, Kovacevic D, Sredojevic S, Dumanovic Z, Drinic Mladenovic S (2010) The variation of phytic and inorganic phosphorus in leaves and grain in maize populations. Genetika 42:555-563

23. Dragičević V, Mladenović Drinić S, Stojiljković M, Filipović M, Dumanović Z (2013) Variability of factors that affect availability of iron, manganese and zinc in maize lines. Genetika 45:907-920

24. Hess SY, Thurnham DI, Hurrell RF (2005) Influence of provitamin A carotenoids on iron, zinc, and vitamin A status. HarvestPlus Technical Monography 6. International Food Policy Research Institute (IFPRI) and International Center for Tropical Agriculture (CIAT), Washington, DC and Cali

25. Beiseigel JM, Hunt JR, Glahn RP, Welch RM, Menkir A, Maziya Dixon BB (2007) Iron bioavailability from maize and beans: a comparison of human measurements with $\mathrm{CacO}-2$ cell and algorithm predictions. Am J Clin Nutr 86:388-396

\section{Submit your manuscript to a SpringerOpen ${ }^{\odot}$ journal and benefit from:}

- Convenient online submission

- Rigorous peer review

- Immediate publication on acceptance

- Open access: articles freely available online

- High visibility within the field

- Retaining the copyright to your article

Submit your next manuscript at $>$ springeropen.com 